\title{
Total Quality Management in the Implementation of Tasks of The Local Community: The Case of Pre-School Education
}

UDK: 005.336.3:373.2

Jože Benčina

University of Ljubliana, Faculty of Administration

joze.bencina@fu.uni-li.si

Srečko Devjak

University of Liubljana, Faculty of Administration

srecko.devjak@fu.uni-li.si

\section{ABSTRACT}

The paper presents the challenge of establishing a substantial governance framework of local government provision of tasks and services. The assumption that this end is highly dependent on the implementation of total quality management paradigm has led us to base our work on the Common Assessment Framework model. The research discusses the case of pre-school education. The main research question is how the representatives of the municipality, responsible for pre-school education, understand their role and accountability in the process of the provision of local government genuine services and tasks. As the main methodological result of the research is approved that the questionnaire based on the CAF model can help to discover the main opportunities for improvement of governance of genuine local government tasks. The results of the survey on pre-school education show that local governments are in control of financial matters and that their strategic focus is limited to the investment aspect. The accountability for quality management was approved as a key opportunity for improvement of local government governance.

Key words: local community, administration, provision of tasks, preschool education, CAF

JEL: D63, D73

Benčina, J. \& Devjak, S. (2011). Total Quality Management in the Implementation

of Tasks of The Local Community: The Case of Pre-School Education.

Uprava, IX(2), 59-82. 


\section{Introduction}

The quality of services implemented by the municipality for satisfying the needs of its inhabitants is crucial for ensuring the quality of life in the municipality. The Local Self-Government Act (ZLS, 2009, Article 49) ${ }^{1}$ defines the original tasks that fall within the competence of the municipality. Furthermore, the act determines that the municipality implements the tasks transferred to the municipality by the state with special acts, whereas the state must ensure relevant additional resources for these services, taking into account especially two provisions from the Local Self-Government Act: »A municipality must be capable of satisfying the needs and interests of its inhabitants and fulfilling other tasks in accordance with the law." (ZLS, 2009, Article 13) and (2) »Municipal administration carries out administrative, professional, promotional and development tasks and tasks concerning the provision of public services within the municipality competence." (ZLS, 2009, Article 49). The local community is fully responsible for the expedient ${ }^{2}$ implementation of original tasks within the meaning of existing legislation.

In this respect, the central question is the implementation of original tasks in the light of administration (effectiveness), management (efficiency) and quality of services by the municipality. The paper deals with the problem of administration, management and provision of quality implementation of original tasks of the municipality from two basic aspects: a) general, which provides for the satisfaction of the needs of inhabitants according to certain types of services and b) professional, which indicates the professional development and quality of services.

Both profit and non-profit organisations achieve the best results only by applying the relevant approach within the framework of Total Quality Management (TQM) and observing the basic principles of benchmarking analysis. The EFQM excellence model ${ }^{3}$ (Kovač \& Kern-Pipan, 2008) is a suitable framework for implementing the total quality management (BouLlusar et al., 2009). The self-assessment approach CAF - Common Assessment Framework is becoming more and more established in

1 Hereinafter, the Local Self-Government Act will be refered as ZLS.

2 Expedient - the concept includes: economy, efficiency, performance, ethics, quality etc.

3 EFQM - European Foundation for Quality Management.

The EFQM excellence model-model that forms the basis for the awards of the European

Foundation for Quality Management. 
the public sector as a tool for the implementation of the EFQM excellence model (Kovač, 2002). Examples of integrated approaches to quality management show that both the organisational aspect and the aspect of implementing the use of tools for quality assurance, such as the CAF or the system of balanced indicators, must be taken into account in the introduction of the approach (Gent, 2006). The EFQM model or the CAF is designed causally and is based on the assumption that the improvement of the state of factors leads to better results. By checking the theoretical grounds with the empirical modelling for data on Polish local communities, it can be determined that the basic factor of the model management has an effect on strategy and planning, which have an effect on employees, who transfer the effect on processes, where the contribution of resources and partnership is seen as well. The processes then have an effect on the results for customers (members of municipalities), forming the key performance results (Bugdol \& Jarzebinski, 2010). On the basis of reviewed bibliography we can conclude that this field has drawn a lot of attention by practitioners and that the implementation of the total quality management in connection with the CAF model in local communities is a rather widespread practice, gradually followed also by increased volume of scientific research papers. However, studies dealing with the problem of assigning roles in quality assurance and similar services in local communities are less frequent; therefore, the results of previous research offer no concrete suitable solutions for the problem in question. For this purpose, this paper will present the manner of using the duly adjusted CAF approach as a tool for assuring the quality of implementation of the local communities' tasks, whose operational implementation has been handed over to the public or private organisations.

The abovementioned issue is presented on the case of pre-school education. The municipality is responsible pre-school education within its area (ZLS, 2009, Article 32). In general, this means that it is responsible for the establishment of kindergartens that operate according to the prescribed programme (The Kindergarten Curriculum, 1999) or for the awarding of a concession for the implementation of prescribed programmes or (generally) co-finances the implementation of pre-school education according to other (alternative) programmes. The administration and management of pre-school education activity includes: The municipality (mayor, municipality bodies and professional staff 
of municipal administration), institute councils, kindergarten management etc. The approaches of quality control with self-assessment established thus far have not been properly applied to the local community, as it must on the one hand work towards excellence, while on the other hand it must monitor and take measures for quality operation of kindergartens and is in charge of their financing and providing investments. Therefore, a problem arises in practise, as the roles in the system of total quality assurance in pre-school education are not clearly differentiated. Thus, local communites do not undertake all tasks and responsibilities required. As a rule, municipalities provide for the material conditions of kindergarten operation, while they assume no specific responsibility for other functions (quality) of pre-school education development and for the efficient operation of pre-school education (Devjak \& Berčnik, 2009). In this manner, the prerequisite for a successful total quality management of preschool education in Slovene municipalities is not fulfilled.

The paper will therefore focus on the issue of total quality management in the relation between the local community - kindergarten and pre-school education provider in the municipality. On the basis of CAF assessment scheme we have drawn up a relevant questionnaire within the "Reggio Emilia" project ${ }^{4}$. The questionnaire was used to answer the following two research questions which are the subject-matter of this paper:

- how the representatives of the local community, responsible for pre-school education, understand their accountability and competence in the process of the provision of quality pre-school education on the basis of all criteria of the CAF model and

- how the local communities (representatives responsible for preschool education) evaluate the factors and results in the field of pre-school education.

4 The project entitled "Professional training of education professionals to implement the elements of special pedagogical principles of the Reggio Emilia concept in the area of preschool education" (2008-2013) is a project financed by the European Social Fund and the Ministry of Education and Sport and is implemented at the Faculty of Education of the University of Ljubljana, project coordinator prof. dr. Tatjana Devjak. 


\section{Service quality management in the local community}

Pre-school education is an important task in Slovene local communities in terms of budget; therefore, its planning and implementation is important. Pre-school education in Slovenia is provided in particular by public kindergartens, and, to a lesser extent, also by private kindergartens. Children of ages from one to the age of entering primary school are enrolled in kindergartens. Pre-school education is not compulsory. The provision of pre-school education is one of the basic tasks of the municipality (Vlai, 2001), as it is in charge of establishing and financing kindergartens.

Pre-school education in Slovene kindergartens is regulated by the following acts: Organization and Financing of Education Act (1996), Kindergarten Act (1996) and Local Self-Government Act (2009). The Organisation and Financing of Education Act regulates the conditions for performing education and defines the manner of administration and financing in all education fields. The Kindergarten Act regulates preschool education that takes place in public and private kindergartens (kindergarten tasks, objectives and principles, possible programme types in kindergarten, financing, conditions for the education of professional staff, workload of childcare workers and assistant childcare workers, collection and protection of personal data in kindergarten etc.)

The establishment and financing of pre-school education is one of the important tasks of the municipality. The competent departments are responsible for arranging the suitable and quality implementation of this activity, otherwise legally and normatively defined (ZLS, 2009 and Kindergarten Act, 2008), however, the attainment of certain standards in the field of pre-school education depends on various factors, interests and needs of individual subsystems (parents, political parties, kindergarten professional staff, municipality professional staff etc.). The quality of implementation of a certain activity in the municipality, in our example pre-school education, often receives insufficient planned and consistent attention due to various factors.

The public administration and municipalities in Slovenia have recently increasingly implemented the European model CAF - Common Assessment Framework for the field of work quality assessment of organisations in the public sector. The model is derived from the EFQM excellence model and represents a tool for the improvement of the 
organisation or public administration by means of self-assessment. This model is also a part of the document entitled Quality Policy of Slovenian Public Administration, adopted by the Government of the Republic of Slovenia on December 2003. The CAF model is a simple framework, appropriate for self-assessment of organisations in the public sector.

The CAF as a model for the implementation of quality and excellence represents the most adapted tool to the public administration, designed for the improvement of its performance. Having accepted the principles of operation, determined the vision, mission and values the administration wants to develop and improve, the CAF model enables the pursuit of objectives, the measurement of results and the achievement of objectives. In this manner, the organisation can monitor and evaluate its actual development of quality and excellence. The essence of this model is especially in that it is based on the inclusion of all employees, users of services and partners. It opens up new possibilities in the understanding and solving of problems with quality and increases the engagement and dynamics within the working collective, which is crucial in the implementation and improvement of the work level in public sector organisations, especially in their relationship with the users of their services.

The CAF model (CAF, 2009) is based on the measurement of quality factors and quality results. The measurement of quality factors is classified into five groups: (1) leadership; (2) strategy and planning; (3) managing people at work; (4) partnerships and resources; (5) administering processes and controlling changes. The measurement of quality results is classified into four groups: (1) customer-oriented results; (2) employeeoriented results; (3) society results and (4) key performance results.

The CAF model can be used by public sector organisations throughout Europe as a tool to facilitate the use of quality management techniques in order to improve their performance. The four main functions of the CAF model are:

1. To include all the specific feature of various organisations in the public sector.

2. To serve as a tool to public sector employees who would like to improve the performance of their organisation.

3. To act as a "bridge" between various models of quality management.

64 Uprava, letnik IX, 2/2011 
4. To enable easier benchmarking with other organisations in the public sector.

The described model can be used in all public sector areas, composed of public organisations on the national, regional or local level. In addition, it can be used in various circumstances, e.g. as a part of the systematic renewal programme or as a basis for determining objectives in the efforts for the improvement of public service organisations. The CAF enables and ensures:

- assessment which is based on evidence,

- the achievement of policy consistency and consensus on the steps necessary for the improvement of the organisation,

- assessment on the basis of defined criteria, widely adopted in Europe,

- periodic self-assessment in order to check the progress,

- a link between the objectives and support strategies and processes,

- the focus of the improvement activity on the most necessary areas,

- the promotion and exchange of good practice among various fields of the organisation and with other organisations,

- the creation enthusiasm among employees by including them into the improvement process,

- opportunities for the recognition of progress and outstanding achievements,

- the inclusion of various quality initiatives for the normal operation.

Various authors (Calvo-Mora et. al 2005; Castresana \& FernándezOrtiz, 2005) prove that the excellence models (the most widely used being the MBNQA $A^{5}$ and the EFQM ${ }^{6}$ models) are a very useful framework for the establishment of total quality management (Bou-Llusar et al., 2009). Compared to the MBNQA and EFQM models, the CAF is a "simple" model, suitable especially for familiarisation with the organisation operation. It is expected that the organisation working towards progress will select one of the more detailed models (such as the Speyer or EFQM model). The advantage of the CAF model is in that it is compatible with

5 Malcolm Baldrige National Quality Award

6 The European Foundation for Quality Management 
the abovementioned models and can thus be used as a first step for the organisation which aims at continuing to manage its own quality.

\section{Methodology}

As mentioned, the standard CAF approach is not completely suitable for addressing specific circumstances in the local community, as the local community must manage pre-school education in relation to the providers of the task. For this purpose, we expanded the questionnaire for the assessment of quality of pre-school education operation on the basis of the CAF model by adding the assessment of respondents' own operation (direct self-assessment) besides the assessment of factors and results for pre-school education providers (indirect self-assessment). The questions for direct self-assessment were not added only in three criteria of excellence (employees and results for employees and society).

On the basis of research questions we formulated the following hypotheses:

- representatives of local communities, responsible for pre-school education, do not work towards total quality management,

- representatives of local communities, responsible for pre-school education, assess their own performance as better or equal as the performance of pre-school education providers.

In testing the first hypothesis, stating that the representatives responsible for the development and operation of pre-school education do not work towards total quality management, we started from the assumption that the local communities should manage the key causal factors of quality assurance (leadership and policy and strategy (Bugdol \& Jarzebinski, 2010)). We tested the hypothesis by looking into the deviations in the questionnaire results, namely by applying:

- the analysis of the range order of arithmetic means of questionnaire results; variables with the results in the second decile show the opportunities for improvement (the elements of excellence criteria with the lowest assessments) and

- the analysis of missing values in questions on the results for customers and employees; deviations in missing values, which apply to the assessment of results, most likely mean that the respondents do not know that these results are being measured or are not familiar with these results. 
The second hypothesis, stating that the representatives of local communities, responsible for the development and operation of preschool education, assess their performance as better or equal as the performance of pre-school education providers, was formulated with the aim of presenting the view of local communities on the operation of preschool education providers and their own contribution. We tested the hypothesis by comparing the assessments of direct self-assessment with the assessments of indirect self-assessment.

The questionnaire comprises 84 questions in 13 sets (the position of kindergartens in the local community (8), 9 CAF criteria (58), understanding of Reggio Emilia pedagogical concept in kindergartens (1), assessment of CAF criteria priorities (9) and general data (8)), most of which include the 5-point Likert assessment scale.

The distribution of questions of the direct (14) and indirect selfassessment (44) is listed in Table 1. As already mentioned, the questions for direct assessment were not assigned to the "employee" and "results for employees and society" factors.

\section{Table 1: The distribution of questions for direct and indirect assessment of CAF criteria}

\begin{tabular}{|l|c|c|c|}
\hline \multirow{2}{*}{ Criteria of excellence } & \multicolumn{3}{|c|}{ Number of questions for self-assessment } \\
\cline { 2 - 4 } & direct & indirect & total \\
\hline Leadership & 1 & 3 & 4 \\
\hline Policy and strategy & 4 & 2 & 6 \\
\hline Employees & 0 & 5 & 5 \\
\hline Partnerships and resources & 2 & 7 & 9 \\
\hline Processes & 3 & 8 & 11 \\
\hline Results - employees & 0 & 5 & 5 \\
\hline Results - customers & 3 & 4 & 7 \\
\hline Results - society & 0 & 8 & 8 \\
\hline Key performance results & 1 & 2 & 3 \\
\hline
\end{tabular}

Source: Municipality research, 2010

The questionnaire was sent to all Slovene municipalities by post in October 2009. The population therefore represents representatives of Slovene municipalities, responsible for pre-school education. We allowed 3 months for the completion of questionnaires. 


\section{Results}

The research deals with Slovene municipalities in the light of administration of pre-school education. In this respect, the municipalities are organised differently, and the number of pre-school education providers varies as well. The research does not observe these differences. The population represents representatives of Slovene municipalities, responsible for pre-school education. The response rate was low, only 20.5\% (43 returned questionnaires from 210 distributed). Clearly, additional effort should be taken to motivate the municipal professional services and make them more interested in participating in these types of research.

Possible sample bias was checked by comparing the frequency distributions in relation to the number of inhabitants of the municipality for the population and sample (Table 2).

Table 2: Comparison of frequency distributions between the population and sample

\begin{tabular}{|r|r|r|r|r|r|}
\hline \multicolumn{2}{|c|}{ Number of inhabitants } & \multicolumn{2}{|c|}{ Population } & \multicolumn{2}{c|}{ Sample } \\
\hline \multicolumn{1}{c|}{ over } & up to & $\mathrm{fi}$ & \multicolumn{1}{c|}{$\mathrm{fi}^{\circ}$} & $\mathrm{fi}$ & $\mathrm{fi}$ \\
\hline & 3000 & 57 & $27.1 \%$ & 7 & $16 \%$ \\
\hline 3000 & 5000 & 53 & $25.2 \%$ & 8 & $19 \%$ \\
\hline 5000 & 10000 & 47 & $22.4 \%$ & 12 & $28 \%$ \\
\hline 10000 & 20000 & 36 & $17.1 \%$ & 9 & $21 \%$ \\
\hline 20000 & 40000 & 12 & $5.7 \%$ & 5 & $12 \%$ \\
\hline 40000 & 300000 & 5 & $2.4 \%$ & 2 & $5 \%$ \\
\hline
\end{tabular}

Source: Municipality research, 2010

The comparison between the relative frequencies shows that the proportion of larger municipalities is slightly higher in the sample than in the basic population. The issue of managing pre-school education is certainly more complex in larger municipalities; therefore, the sample is surely suitable for addressing this phenomenon, whereas possible differences between smaller and larger municipalities should be checked in further research.

The review of respondent according to statistical regions shows that the regional representation of municipalities is slightly unbalanced; the 
majority of municipalities that completed the questionnaire come from the Gorizia and Central Slovenia region.

In testing the hypotheses, we took into account the first two sets of questions (the position of kindergartens in the local community (8), 9 CAF criteria (58)).

The first hypothesis stating:

- representatives of local communities, responsible for pre-school education, do not work towards total quality management,

was checked by analysing the range order of arithmetic means of questionnaire results. In some questions, which form an important part of quality management, the proportion of missing answers was rather high; therefore, within the reflection on the hypothesis, an analysis of missing values was drawn up as well.

From the range order of arithmetic means of all variables concerned the variables with arithmetic means smaller or equal to the $2^{\text {nd }}$ decile (3.41) were selected. All variables, where one-sample t-test on the value from the $2^{\text {nd }}$ decile shows that the variables cannot be differentiated from the values of the $2^{\text {nd }}$ decile, were also taken into account. In this manner, a group of 12 variables with the lowest assessments was determined (Table 3).

The first two questions are from the set of assessing the cooperation of local community with pre-school education providers. The calculated values are far the lowest among the eight questions in this field. Other elements of cooperation in the field of financing and general state of preschool education are significantly higher assessed by respondents than personal engagement in the control of quality and efficiency of pre-school education implementation.

Among the assessment values for policy and strategy the assessment of strategy realisation deviates the most. Respondents assess the situation regarding the definition of mission, vision and strategy significantly better, which means that they are aware of the difficult realisation of policy and strategy. Lower assessments within the policy and strategy criteria include the assessment of planning and measurement of performance and effectiveness in kindergartens. 
Table 3: Review of variables with the arithmetic mean lower or equal to the $2^{\text {nd }}$ decile (3.41)

\begin{tabular}{|c|c|c|}
\hline Question & $\begin{array}{c}\text { Arithmetic } \\
\text { mean }\end{array}$ & CAF criteria \\
\hline $\begin{array}{l}\text { The frequency of monitoring the quality of work in } \\
\text { kindergarten }\end{array}$ & 3,38 & leadership \\
\hline Monitoring work efficiency in kindergarten & 3,28 & leadership \\
\hline $\begin{array}{l}\text { Kindergarten managements endeavour to implement the } \\
\text { models and standards of quality, such as CAF, ISO. }\end{array}$ & 3,44 & leadership \\
\hline $\begin{array}{l}\text { The municipality has drawn up a development strategy } \\
\text { for pre-school education, which is observed by the } \\
\text { bodies of the municipality. }\end{array}$ & 2,98 & $\begin{array}{l}\text { policy and } \\
\text { strategy }\end{array}$ \\
\hline $\begin{array}{l}\text { The objectives for measuring the performance and } \\
\text { effectiveness of implementation of pre-school education } \\
\text { are formulated regularly in kindergartens and the } \\
\text { attainment of these objectives is analysed regularly. }\end{array}$ & 3,49 & $\begin{array}{l}\text { policy and } \\
\text { strategy }\end{array}$ \\
\hline $\begin{array}{l}\text { The community's assessment of the quality of the flow of } \\
\text { information and knowledge between research institutions } \\
\text { concerned with pre-school education, e.g. the faculty } \\
\text { and kindergartens. }\end{array}$ & 3,18 & $\begin{array}{l}\text { partnerships } \\
\text { and resources }\end{array}$ \\
\hline $\begin{array}{l}\text { The local community's opinion on the quality of the flow } \\
\text { of information and knowledge between the National } \\
\text { Education Institute and kindergarten. }\end{array}$ & 3,36 & $\begin{array}{l}\text { partnerships } \\
\text { and resources }\end{array}$ \\
\hline $\begin{array}{l}\text { The local community's opinion on the quality of the flow } \\
\text { of information and knowledge between the Social Work } \\
\text { Centre, kindergarten and local community. }\end{array}$ & 3,33 & $\begin{array}{l}\text { partnerships } \\
\text { and resources }\end{array}$ \\
\hline $\begin{array}{l}\text { Kindergartens encourage parents and other citizens } \\
\text { (individuals) to participate in the implementation of pre- } \\
\text { school education and other activities, which are } \\
\text { important for improving the quality in kindergartens } \\
\text { (opinion polls, quality circles, surveys etc.). }\end{array}$ & 3,67 & $\begin{array}{l}\text { partnerships } \\
\text { and resources }\end{array}$ \\
\hline $\begin{array}{l}\text { Kindergartens regularly inform the public on the } \\
\text { conditions and results of pre-school education in } \\
\text { comparison with similar organisations. }\end{array}$ & 3,38 & $\begin{array}{l}\text { partnerships } \\
\text { and resources }\end{array}$ \\
\hline $\begin{array}{l}\text { Kindergartens ensure a physical accessibility to buildings } \\
\text { and facilities (parking lots, access for disabled people, } \\
\text { public transportation etc.). }\end{array}$ & 3,64 & $\begin{array}{l}\text { partnerships } \\
\text { and resources }\end{array}$ \\
\hline $\begin{array}{l}\text { Kindergarten actively informs the general public in the } \\
\text { local community on the latest findings in the field of pre- } \\
\text { school education. }\end{array}$ & 3,14 & $\begin{array}{l}\text { results - } \\
\text { society }\end{array}$ \\
\hline
\end{tabular}

Source: Municipality research, 2010 
As many as six from nine variable of the partnership criteria were ranked among the variables with lowest assessments. In society results the lowest assessment was recorded for the question checking one of the elements of the Reggio Emilia pre-school education concept, namely the responsibility of providers to inform and transfer the knowledge into the general public.

The analysis of variables with the lowest values shows that the opportunities from improvement are especially in three factors, i.e. leadership, policy and strategy and partnerships. Taking into account the results of modelling causal connections in the CAF model (Bugdol \& Jarzebinski, 2010), which highlights leadership and policy and strategy as key factors, it can be assumed that the improvement of both causal factors could have a significant effect on the improvement of results of pre-school education activities.

With the analysis of missing values variables with a detected proportion of missing answers higher than 20\% were checked as well (Table 4).

The first question from the table contained an error in the questionnaire, as the assessment table did not contain values for selection, therefore many respondents overlooked this answer.

All other variables in Table 4 apply to customer-oriented results, except one which applies to employee-oriented results. In the preparation of the questionnaire we did not take into account the possibility of such large amount of unanswered questions; therefore it was not completely adapted to checking the actual reason for non-response. Nevertheless, it may be concluded that the reason for several missing values is the failure to perform measurements or familiarise with the results of measurements for customer-oriented results. On the basis of given facts it may be concluded that the representatives of municipal administrations, responsible for pre-school education, do not manage customer-oriented results.

It is evident from the reflection of the content that the biggest opportunities for improvement are connected with two main factors of the CAF model, i.e. leadership and policy and strategy, which are also the key levers for the achievement of good results. The missing answers among questions on the implementation and results of checking customer satisfaction show that the representatives of municipalities, responsible for 
pre-school education, do not manage results of kindergarten operation. Collected facts reveal essential opportunities for improvement in the field of administration of pre-school education activity regarding the factors: leadership, policy and strategy and partnerships and resources, as well as customer-oriented results.

Table 4: Review of variables with the proportion of deviation of missing values

\begin{tabular}{|c|c|c|c|c|}
\hline \multirow[b]{2}{*}{ Question } & \multicolumn{2}{|c|}{ Missing answers } & \multirow{2}{*}{$\begin{array}{l}\text { Arithmetic } \\
\text { mean }\end{array}$} & \multirow{2}{*}{$\begin{array}{l}\text { CAF } \\
\text { criteria }\end{array}$} \\
\hline & number & $\begin{array}{r}\text { propor- } \\
\text { tion }\end{array}$ & & \\
\hline $\begin{array}{l}\text { Kindergartens have elaborated their } \\
\text { development strategies. }\end{array}$ & 22 & $51,2 \%$ & 3,62 & $\begin{array}{l}\text { policy and } \\
\text { strategy }\end{array}$ \\
\hline $\begin{array}{l}\text { Employee satisfaction surveys are } \\
\text { performed regularly in kindergartens. }\end{array}$ & 12 & $27,9 \%$ & 3,00 & employees \\
\hline $\begin{array}{l}\text { Surveys on parent satisfaction with pre- } \\
\text { school education are performed regularly } \\
\text { in kindergartens. }\end{array}$ & 9 & $20,9 \%$ & 2,35 & $\begin{array}{l}\text { customer- } \\
\text { oriented } \\
\text { results }\end{array}$ \\
\hline $\begin{array}{l}\text { Obtained results of parent satisfaction } \\
\text { surveys are in accordance with the } \\
\text { expectations of parents. }\end{array}$ & 20 & $46,5 \%$ & 3,70 & $\begin{array}{l}\text { customer- } \\
\text { oriented } \\
\text { results }\end{array}$ \\
\hline $\begin{array}{l}\text { Obtained results of parent satisfaction } \\
\text { surveys are in accordance with the policy } \\
\text { and strategy of pre-school education. }\end{array}$ & 20 & $46,5 \%$ & 3,78 & $\begin{array}{l}\text { customer- } \\
\text { oriented } \\
\text { results }\end{array}$ \\
\hline $\begin{array}{l}\text { Obtained results of parent satisfaction } \\
\text { surveys show that errors and accidents } \\
\text { occur rarely in kindergartens. }\end{array}$ & 21 & $48,8 \%$ & 4,23 & $\begin{array}{l}\text { customer- } \\
\text { oriented } \\
\text { results }\end{array}$ \\
\hline $\begin{array}{l}\text { Obtained results of parent satisfaction } \\
\text { surveys, performed by the municipality, } \\
\text { are in accordance with the expectations } \\
\text { of parents. }\end{array}$ & 31 & $72,1 \%$ & 3,33 & $\begin{array}{l}\text { customer- } \\
\text { oriented } \\
\text { results }\end{array}$ \\
\hline $\begin{array}{l}\text { Obtained results of parent satisfaction } \\
\text { surveys, performed by the municipality, } \\
\text { are in accordance with the policy and } \\
\text { strategy of pre-school education in the } \\
\text { municipality. }\end{array}$ & 31 & $72,1 \%$ & 3,58 & $\begin{array}{l}\text { customer- } \\
\text { oriented } \\
\text { results }\end{array}$ \\
\hline $\begin{array}{l}\text { Results of employee satisfaction survey } \\
\text { are above average. }\end{array}$ & 21 & $48,8 \%$ & 3,14 & $\begin{array}{l}\text { employee- } \\
\text { oriented } \\
\text { results }\end{array}$ \\
\hline
\end{tabular}

Source: Municipality research, 2010 
The second hypothesis stating:

- representatives of local communities, responsible for pre-school education, assess their own operation (direct assessment of operation) as better or the equal to the operation of pre-school education providers (indirect assessment of operation).

was tested by comparing the assessments of direct self-assessment with the assessments of indirect self-assessment. The hypothesis will be confirmed if all comparisons according to elements of the CAF model (factors and results) between the pairs of variable of both categories will show that the arithmetic means of variable values representing indirect assessment are larger or equal to the arithmetic mean of variables representing direct assessment.

Respondents assessed their operation by answering a set of questions on cooperation of local community with kindergartens and selected questions in sets for CAF criteria. Questions from the set on the cooperation of local community with kindergartens, which serve as the self-assessment of local community operation in respect of the financial and professional support, the observance of suggestions of parents and pre-school education providers and the provision of quality and efficiency of operation, were meaningfully classified into relevant CAF criteria. Table 5 shows the values of arithmetic means for direct and indirect selfassessments according to individual CAF criteria. The hypothesis was tested by checking the statistical characteristics of differences between arithmetic means of individual variables from both classes (direct and indirect self-assessment) on the basis of elements of the CAF model.

Among six criteria, where the respondents provided direct and indirect assessments (written in italics), the point estimate of arithmetic mean of direct assessment (assessment of own work) in four criteria (leadership, policy and strategy, partnerships and resources and key performance results) was larger than the indirect assessment (assessments of pre-school education providers), while in two criteria (processes and customeroriented results (achievements)) it was the same. On the basis of this starting point it may be expected that the formulated hypotheses, which state that all comparisons of variables of direct and indirect assessment within the framework of elements of the CAF model will show that direct assessments are always larger or equal to indirect, will not be confirmed. 
The results of comparisons are presented by each CAF element and our views on the validity of the hypothesis are explained with each element.

Table 5: Review of variables with the proportion of deviation of missing values

\begin{tabular}{|c|c|c|c|c|}
\hline \multirow[b]{2}{*}{ CAF criteria } & \multicolumn{2}{|c|}{ Direct self-assessment } & \multicolumn{2}{|c|}{ Indirect self-assessment } \\
\hline & $\begin{array}{c}\text { number of } \\
\text { variables }\end{array}$ & $\begin{array}{c}\text { arithmetic } \\
\text { mean }\end{array}$ & $\begin{array}{l}\text { number of } \\
\text { variables }\end{array}$ & $\begin{array}{c}\text { arithmetic } \\
\text { mean }\end{array}$ \\
\hline Leadership & 2 & 4.36 & 3 & 4.77 \\
\hline Policy and strategy & 4 & 3.67 & 2 & 3.49 \\
\hline Employees & 0 & & 5 & 3.87 \\
\hline Partnerships & 4 & 3.88 & 4 & 3.47 \\
\hline Resources & 2 & 4.47 & 3 & 3.88 \\
\hline Processes a (yes/no) & 3 & 1.36 & 2 & 1.40 \\
\hline Processes b (1-5) & 2 & 3.33 & 6 & 4.04 \\
\hline Results - employees & 0 & & 5 & 3.49 \\
\hline $\begin{array}{l}\text { Results - customers (conducting } \\
\text { surveys) }\end{array}$ & 7 & 3.30 & 7 & 2.36 \\
\hline $\begin{array}{l}\text { Results - customers } \\
\text { (achievements) }\end{array}$ & 2 & 3.46 & 2 & 3.77 \\
\hline Results - society & 0 & & 8 & 4.03 \\
\hline Key performance results & 2 & 4.24 & 2 & 4.12 \\
\hline
\end{tabular}

Source: Municipality research, 2010

All point estimates of direct assessment in the leadership factor are higher than point estimates of indirect assessment, whereas only in one of the six pairs the difference, tested by means of pair t-test, is not statistically significant. Thus, the hypothesis that the estimates of direct assessment are higher or equal to estimates of indirect assessment for the leadership factor can be confirmed.

In variables applying to the policy and strategy factor the variable "Kindergartens have elaborated their development strategies" was eliminated from the study due to high proportion of missing values, reducing the variables for comparison to a single one applying to the operation of kindergartens. The sample estimate for the arithmetic mean of direct self-assessment is lower than indirect self-assessment only in one pair (low estimate of the statement "The municipality has drawn up a

74 Uprava, letnik IX, 2/2011 
development strategy for pre-school education, which is observed by the bodies of the municipality"); however, this difference is not statistically significant (the result of pair t-test $p=0.080$ ). The hypothesis for the partnership and resources factor can also be confirmed (the remaining three pairs have higher direct assessments, one of which is also statistically significant), with a remark that the representatives of municipalities, responsible for pre-school education, start implementing the strategies and are critical of the results of their effort in this area.

The comparison within the framework of the partnerships and resources variable was divided to partnerships and resources separately. The partnership variable comprises four variables of direct and indirect assessment. Among sixteen compared pairs, the point estimate of direct assessment was smaller than indirect in two pairs, however, the difference is not statistically significant. In the remaining pairs with larger sample value of direct assessment the difference was statistically significant in as many as ten pairs of fourteen pairs. The partnership hypothesis in the partnerships and resources factor can therefore be confirmed. The analysis of the resources factor comprises 6 variables. Sample values of direct assessment in all pairs are higher than sample estimates of indirect assessment. Testing with the pair t-test does not confirm differences only in one pair. Therefore, the hypothesis can be confirmed on the complete partnership and resources factor with the remark that the differences are considerable, as they are confirmed as statistically significant in most of pair testing.

In the assessment of processes two sets of variable were used, 5 variables with binomial assessment scale and 8 variables with five-level assessment scale. In the set of variables with binomial scale the arithmetic means of direct and indirect assessments are almost equal; however, statistically significant differences between arithmetic means in favour of indirect assessments occur in as many as two pairs. Thus, the hypothesis on the processes factor is rejected already in the first part of variables concerned. The comparison of arithmetic means of the remaining assessments of the processes factor again shows that the sample values of direct assessments of activities are lower than indirect assessment. The statement is valid also after the performed testing with the pair t-test, as the higher indirect assessments in all pair are also statistically significant. The hypothesis on the processes factor is rejected, in practice, it can be 
concluded that all direct assessments are lower than (or equal to) the indirect assessments with this factor.

The assessment of customer-oriented results was performed with two sets of variables. The first comparable pair was the assessment of frequency of implementation of parent satisfaction surveys by municipalities and kindergartens separately. The result with the statistical characteristic ( $p=0.000$ ) shows that the representatives of municipal administrations believe that the municipalities perform measurements of customer satisfaction on a more regular basis than kindergartens. The comparisons of result assessments show that the assessments of surveys performed by municipalities are lower than the assessments of assessments performed by kindergartens; however, this result cannot be used due to a large proportion of missing values. Thus, it is reasonable to exclude customer-oriented results from our hypothesis due to a small sample $(\mathrm{n}=11)$.

In key performance results two variables of both direct and indirect assessment were compared. In two pairs of variables the point estimate of arithmetic mean of direct assessment is higher than indirect, and vice versa in other two pairs. The differences are statistically significant only in differences in favour of the direct assessment; therefore, the formulated hypothesis for key performance results can be confirmed.

Clearly, the null hypothesis stating that the local communities' assessment of their own activities is lower than the activities of pre-school education providers in at least one variable cannot be rejected. The review of results of testing the hypothesis according to individual elements of the CAF model shows that the null hypothesis stating that the local communities' assessment of their own activities is lower than the activities of pre-school education providers is rejected in factors: leadership, policy and strategy, partnerships and resources and key performance results. Thus, the alternative hypothesis that the arithmetic means of direct assessments in all compared pairs of variables are higher or equal to arithmetic means of indirect assessments is confirmed for the abovementioned factors and key performance results. The null hypothesis in the processes and customer-oriented results factors cannot be rejected, as at least one pair of variables occurs in both factors, where the statistical significance of arithmetic mean of direct assessment is lower than that of compared indirect assessment. 


\section{Discussion}

We tried to answer the two research questions:

- how the representatives of the local community, responsible for pre-school education, understand their accountability and competence in the process of the provision of quality pre-school education on the basis of all criteria of the CAF model and

- how the local communities (representatives responsible for preschool education) evaluate the factors and results in the field of pre-school education.

by applying two hypotheses:

- representatives of local communities, responsible for pre-school education, do not work towards total quality management and

- representatives of local communities, responsible for pre-school education, assess their own operation as better or equal to the operation of pre-school education providers.

A small sample and a large proportion of missing answers in certain questions slightly limit the generalisation of results. However, since the research was targeted at familiarisation with the problem area, we can accept these results as a good starting point for planned further research.

On the basis of results of the research we can conclude that the management and implementation of tasks in local communities offer several opportunities for improvement:

- representatives of local communities are not aware of their key role in the establishment of total quality management in the implementation of tasks within their competence,

- they are relatively satisfied with their contribution and the condition in the field of implementation of tasks within their competence,

- they are slightly biased in the assessment of activities and results, they assess their own contribution as better than the contribution of activity providers.

The abovementioned facts, for which it can be assumed that they are not limited only to the field concerned, were illustrated on the case of preschool education, where we can conclude on the basis of results that municipal administrations only partially monitor the operation of preschool education providers and that they have not developed the grounds 
and concept for working towards the total quality management. Final opportunities for improvement include:

- the control of quality and efficiency,

- the implementation of strategy,

- partnership and resources and

- customer-oriented results.

Missing answers in questions applying to customer-oriented results imply that the control of results should be checked and improved in the first step in order to establish a stable controlling. In further research and search for solutions the issue of partnership should be taken into account, where results of the research indicate the passive approach of problem identification and failure to understand the local community's own role and responsibility for the development of the field.

The treatment of the second hypothesis only supported the findings regarding the failure to identify the problem. A slightly higher assessment of own operation than the assessment of providers' operation indicates that municipal administrations are likely to recognise their operation as less problematic and that key responsibilities for quality operation of tasks are assigned to providers.

\section{Conclusion}

The paper presents the problem of managing the activities of implementation of tasks in local communities. On the basis of the premise that total quality management is a key starting point for the development of this field, we disclosed the opportunities for improvement by applying the CAF model. The basic problem of total quality management in the implementation of local community tasks proved to be the unclear distribution of responsibilities regarding the implementation of these tasks.

We confirmed the premise that the role of self-assessors (local community $\leftrightarrow$ provider of the task) must be taken into account in assessment or self-assessment and that the model must include direct selfassessment (the assessment of own activity) and indirect self-assessment (the assessment of activities performed by others). The cross-assessment discloses the understanding of responsibilities and roles of bodies (local community, providers of tasks), which enables a study of individual examples in the light of models of good practice. 
Regulatory framework and general rules of local community operation bind the representatives to establish a firm management framework, supported by relevant comprehensive approach to total quality management. The area requires more research, as the theoretical grounds are too vague to be put into practice effortlessly. The problem therefore represents a major challenge both for researchers and practitioners. A theoretical framework is to be developed, recommendations of good practise are to be drawn up, the transfer of knowledge is to be ensured and professional support in the implementation of the abovementioned is to be offered.

Jože Benčina, PhD, is an Assistant Professor at the Faculty of Administration for the field of economics of public sector. He obtained a BSc in Mathematics, an MSc and a PhD in Information and Management Sciences in 2004 at the Faculty of Economics at the University of Ljubliana. He worked for about ten years as a self entrepreneur as a consultant for the field of informatics and after that for about same time as a manager of Centre for User Support at Government Centre of Informatics. He has been regularly employed at the University of Ljubliana since 2006. His research includes methods for the measurement of public sector performance and methods for the optimisation of decision making in public sector with the use of fuzzy logic. Within his research, he developed and applied special models, such as decision making model for local governments, balanced scorecard for public sector based on the model of fuzzy aggregation trees and indicators of investment efficiency in health care. He regularly presents the results of research in lectures at foreign universities and anticles in relevant international publications.

Sreckko Deviak, PhD, is a Full Professor at the Faculty of Administration for the field of quantitative analyses for administration support. He obtained a BSc in Mathematics, an MSc in Operation Research and a PhD in Information and Management Sciences in 1987 at the Faculty of Economics at the University of Ljubljana. From 1975 to 1992, he worked as a consultant for the field of business economics and organisation development in leading Slovenian consulting institutes. He has been regularly employed at the University of Ljubliana since 1992. From 1998 to 2005, he was Vice-Dean for Study and Student Affairs and from 2005 to 2009 he held the post of Dean at the Faculty of Administration. His research includes methods for the optimisation of operation of various 
Jože Benčina, Srečko Devjak

Total Quality Management in the Implementation of Tasks

of The Local Community: The Case of Pre-School Education

organizational systems. Within his research, he developed and applied special models, such as Forest Balance in Slovenia, Budget Indicators of Municipalities and Indicators of Investment Efficiency in Health Care. He regularly presents the results of research in lectures at foreign universities and articles in relevant international publications.

80 Uprava, letnik IX, 2/2011 


\section{References}

- Bou-Llusar, J.C. et al. (2009). An empirical assessment of the EFQM Excellence Model: Evaluation as a TQM framework relative to the MBNQA Model. Journal of Operations Management 27(1), 1-22.

- Bugdol, M. \& Jarzebinski, M. (2010). The Possibilities of Applying the Common Assessment Framework Model in Service quality Improvement. Organizacijo Vadyba: Sisteminiai Tyrimai (55), 41-53.

- CAF (2009). Skupni ocenjevalni okvir za organizacije v javnem sektoriu. Pridoblieno 2. 7. 2010, s http://www.mju.gov.si/si/delovna_podrocja/kakovost_v_javni_upravi/skupni _ocenjevalni_okvir_caf/

- Calvo-Mora, A., Leal, A. \& Roldán, J. L. (2005). Relationships between the EFQM Model Criteria: a study in Spanish Universities. Total Quality Management 16(6), 741-770.

- Castresana, J. I. \& Fernández-Ortiz, R. (2005). Theoretical foundation of the EFQM Model: the resource-based view. Total Quality Management 16(1), $31-55$.

- Devjak, T. \& Berčnik, S. (2009). Parents' views on preshool care and education in local community. US-China education review 6(7), 68-78. Retrieved 16. 6. 2011 from $\mathrm{http}: / / \mathrm{www}$.airiti.com/ceps/ec_en/ecjnlarticleView.aspx?jnlcattype =0\&jnlpty pe $=0$ \& jnltype $=0$ \&jnliid $=3445$ \&issueiid $=86429$ \&atliid $=1717124$

- Ghent (2006). TQM with CAF and BSC as sustaining systems. The 4th Quality Conference for Public Administrations in the EU - Building Sustainable Quality. Retrieved 30. 5. 2011 from http://www.4qconference.org/liitetiedostot/bp_long_descriptions/BelgiumA_I ong.pdf

- Kovač, P. (2002). Zakaj in kako uvesti evropski model kakovosti Common Assessment Framework - CAF tudi v slovensko upravo. Ljubljana: Ministry of Internal Affairs, Office for Organisation and Development of Administration.

- Kovač, P. \& Kern-Pipan K. (2005). Celovito izboliševanje javne uprave z integracijo različnih pristopov na temelju modela odlicnosti EFQM. Collection of summaries, Conference entitled Modern Public Administration (Sodobna javna uprava), Slovenia, Portorož, 23 - 25 May 2005

- Municipality research (2010). Collected data for local community surveys, pre-school education. Available at: https://docs.google.com/fileview?id=0B7wT5WqiJpPSZDQ1MDdhYmY†O WQxZCO0MDRhLWlyMTItYmQ3NjU2NTUxODZl\&hl=en, or 
Jože Benčina, Srečko Devjak

Total Quality Management in the Implementation of Tasks

of The Local Community: The Case of Pre-School Education

https://docs.google.com/leaf?id=0B7wT5WqiJpPSOGNiOWU4ZiQtMWQ 5NC00ZTNiLTkyMjctM2U5NmM5NDU4NmQw\&hl=en.

- Vlaj, S. (2001). Lokalna samouprava. Ljubliana: Visoka upravna šola.

\section{Legal sources}

- Kindergarten Act. Official Gazette of the Republic of Slovenia, 12/1996, 44/2000, 78/2003, 100/2005, 25/2008.

- Local Self-Government Act. Official Gazette of the Republic of Slovenia, 72/1993, 6/1994, 20/1995, 44/1996, 26/1997, 70/2000, 108/2003 and 60 and $94 / 2007$.

- Organisation and Financing of Education Act (ZOFVI). Official Gazette of the Republic of Slovenia, 12/ 1996, 16/2007 and 22/2009.

82 Uprava, letnik IX, 2/2011 